\title{
UMA NOVA ESPÉCIE DE TAPERINHA LINNAVUORI (HOMOPTERA, CICADELLIDAE, DELTOCEPHALINAE) ${ }^{1}$
}

\author{
Keti Maria Rocha Zanol ${ }^{2}$
}

\begin{abstract}
A NEW SPECIES OF TAPERINHA LINNA VUORI (HoMOPTERA, CiCADELlidAE, DeltocephalinaE). Taperinha marinonii sp.n., from Paraná, Brazil, is described and ilustrated.

KEY WORDS. Cicadellidae, Deltocephalinae, Homoptera, Taperinha
\end{abstract}

\section{Taperinha marinonii sp.n.}

Figs 1-8

Holótipo macho. Cabeça, em vista dorsal, mais longa medianamente do que junto aos olhos, mais larga que o pronoto. Região frontal levemente elevada com microesculturações. Ocelos grandes, situados na margem anterior, visíveis de cima. Área ocelo-ocular aproximadamente quatro vezes menor que o diâmetro dos ocelos. Sutura coronal longa, ultrapassando a metade do vértice. Coloração geral marfim com manchas amarelas na margem anterior e junto aos ocelos; região discal com duas manchas alaranjadas contornadas de amarelo. Face mais ou menos achatada e de coloração marrom. Genas com reentrância abaixo dos olhos. Anteclípeo mais largo no ápice.

Pronoto convexo, superfície lisa de coloração marfim com dez manchas amarelas, na margem anterior e duas, sobre o disco, de contorno irregular, marrons. Escutelo com triângulos basais e uma faixa longitudinal que se estende desde a base até o ápice, amarelos; seis manchas arredondadas: duas sobre o disco e duas de cada lado, nas margens, marrons. Tégminas com três células anteapicais. Veias extranumerárias na margem costal, na célula anteapical central, na primeira célula discal e no clavo. Coloração esbranquiçada com uma grande mancha mais ou menos triangular, com sua base na margem anal e o ápice na altura da segunda célula discal, mancha esta formada por áreas e pontos esparsos marrom-escuros e duas pequenas áreas arredondadas, destituídas de pontos, junto à margem anal; margem costal com triângulos marrom-escuros; células anteapicais, central e interna, pontuadas de marrom-escuro; células apicais marrom-claras. Apêndice desenvolvido. Venação marrom. Espinulação dos fềmures posteriores $2+2+1$ e das tíbias anteriores $1+4$.

Genitália. Placas subgenitais triangulares; macrocerdas na margem externa em fileira dupla no terço basal e depois unisseriadas. Pigóforo com dois pares de

1) Contribuição número 986 do Departamento de Zoologia, Universidade Federal do Paraná.

2) Departamento de Zoologia, Universidade Federal do Paraná. Caixa Postal 19020, 81531-990 Curitiba, Paraná, Brasil. Bolsista do CNPq. 


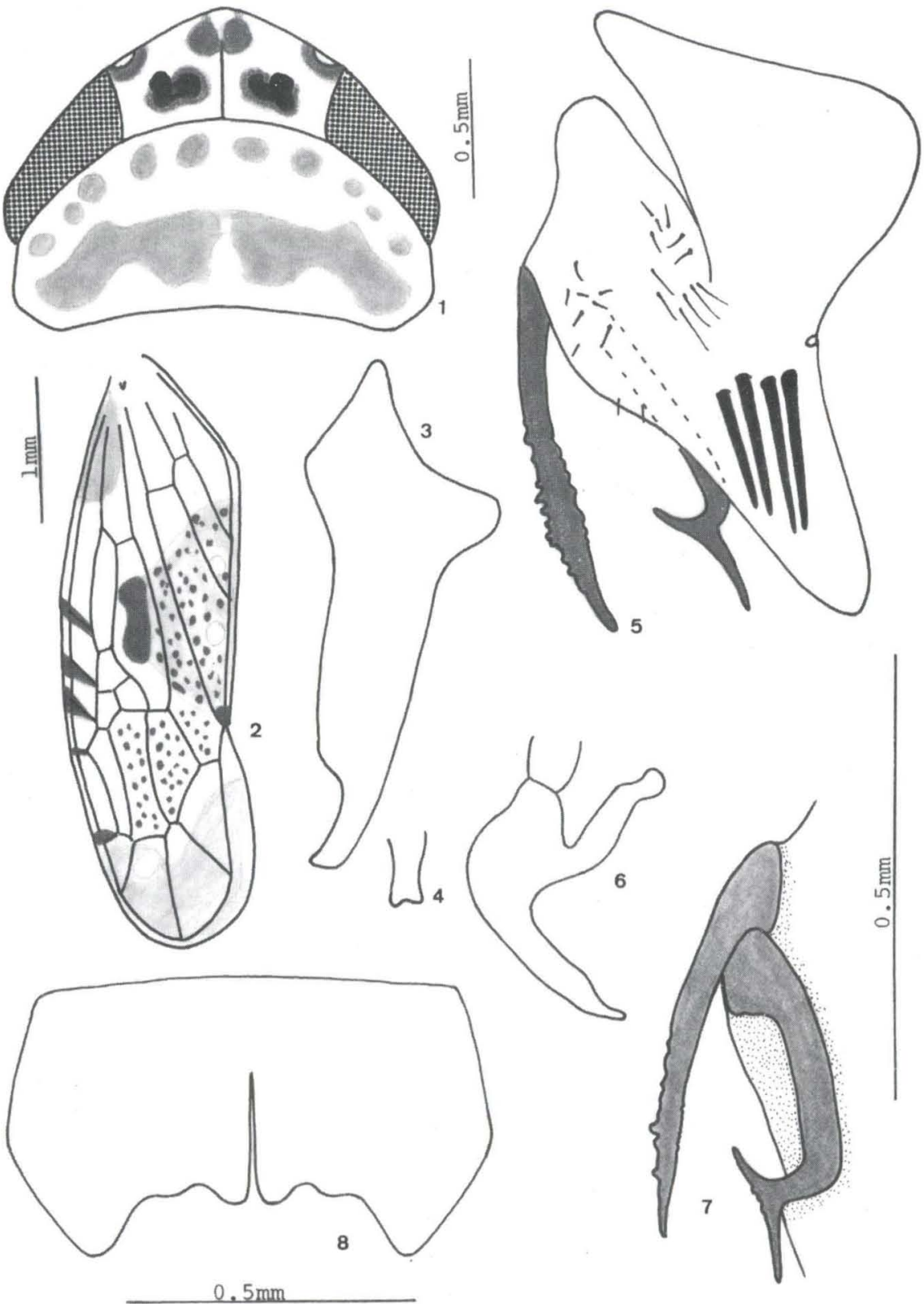

Figs 1-8. Taperinha marinonii sp.n. (1) Cabeça e pronoto, dorsal; (2) tégmina; (3) estilo; (4) ápice do estilo; (5) pigóforo, lateral; (6) edeago, lateral; (7) apêndices do pigóforo, lateral por dentro; (8) sétimo esternito (fêmea). 
apêndices ventrais partindo do mesmo ponto, voltados para trás; o par basal sinuoso com os lados serreados e, o par apical com a extremidade curvada para fora; ápice finamente serreado e projetado para os lados. Estilos digitiformes; ápice bilobado. Edeago simétrico, tubular, curvo, com ápice bífido.

Fêmea. Semelhante ao macho. Sétimo esternito com a metade látero-apical convergente; margem posterior côncava, sinuosa com uma fenda mediana que ultrapassa a metade do comprimento da placa.

Medidas (em milímetros), macho/fêmea. Comprimento total:4,80/4,80.

Material examinado: Holótipo macho. BRASIL, Paraná: Fênix (Reserva Estadual ITCF), 3.X.1986, Lev. Ent. Profaupar leg.. Parátipos: Ibidem, 29.III.1987, 2 fêmeas, 1 macho; 7.VII.1987, 1 fêmea; 29.XII.1986, 1 fêmea, 1 macho; 29.I.1987, 2 fềmeas, 2 machos; 28.V.1987, 1 fêmea; 30.XI.1986, 5 fềmeas, 2 machos; 31.XII.1986, 1 fêmea; 13.XI.1986, 2 fêmeas. (Coleção de Entomologia Pe J.S. Moure, Departamento de Zoologia, Universidade Federal do Paraná).

Comentário. Está espécie é muito parecida com T. bifurcata Linnavuori, 1959 diferindo na forma da concavidade da margem posterior do sétimo esternito da fêmea. O ápice do estilo é bilobado e os apêndices do pigóforo com o par mais basal apresentando os dois lados serreados; a extremidade apical do apêndice apical é finamente serreada e projetada para os lados.

Espécie dedicada ao Prof. Dr. Renato Contin Marinoni, Departamento de Zoologia, Universidade Federal do Paraná, Coordenador do projeto PROFAUPAR. Este projeto, de Levantamento da Fauna Entomológica do Estado do Paraná, permitiu a coleta dos exemplares aqui estudados.

\section{REFERÊNCIAS BIBLIOGRÁFICAS}

LiNNAVUORI, R. 1959. Revision of the neotropical Deltocephalinae and some related subfamilies (Homoptera). Ann. zool. Soc. Bot. fennicae Vanamo 20 (1): $1-370$.

LinNavuori, R. \& D.M. DeLong. 1978. Neotropical leafhoppers of the Bahita group (Homoptera, Cicadellidae, Deltocephalinae). Brenesia 14-15: 109-169. ZANOL, K.M.R. 1988. Descrição de cinco espécies novas de Taperinha Linnavuori, 1959 (Homoptera: Cicadellidae). Revta bras. Ent. 32 (3/4): 411-415.

- 1989 Descrição de duas espécies novas de Taperinha Linnavuori, 1959 (Homoptera, Cicadellidae, Deltocephalinae). Revta bras. Zool. 6 (2): 255-258.

Recebido em 12.XII.1996; aceito em 04.IX.1997. 